\title{
Determination of a Suitable Solar Radiation Model for the Sites of Chad
}

\author{
Marcel Hamda Soulouknga ${ }^{1^{*}}$, Ruben Zieba Falama ${ }^{1,2}$, Oluseyi Olanrewaju Ajayi ${ }^{3}$, \\ Serge Yamigno Doka ${ }^{4}$, Timoleon Crepin Kofane ${ }^{5,6}$ \\ ${ }^{1}$ Department of Physics, Faculty of Sciences, University of Maroua, Maroua, Cameroon \\ ${ }^{2}$ Laboratory of Energy Research, Institute of Geological and Mining Research, Yaoundé, Cameroon \\ ${ }^{3}$ Mechanical Engineering Department, Covenant University, Ota, Nigeria \\ ${ }^{4}$ Department of Physics, Faculty of Science, University of Ngaoundere, Ngaoundere, Cameroon \\ ${ }^{5}$ Department of Physics, Faculty of Science, The University of Yaounde I, Yaoundé, Cameroon \\ ${ }^{6}$ Centre d'Excellence Africain en Technologie de l'Information et de la Communication, The University of Yaounde I, Yaoundé, \\ Cameroon \\ Email: *marcelhamda@yahoo.fr
}

How to cite this paper: Soulouknga, M.H., Falama, R.Z., Ajayi, O.O., Doka, S.Y. and Kofane, T.C. (2017) Determination of a Suitable Solar Radiation Model for the Sites of Chad. Energy and Power Engineering, 9, 703-722.

https://doi.org/10.4236/epe.2017.912045

Received: October 8, 2017

Accepted: October 31, 2017

Published: November 3, 2017

Copyright $\odot 2017$ by authors and Scientific Research Publishing Inc. This work is licensed under the Creative Commons Attribution International License (CC BY 4.0).

http://creativecommons.org/licenses/by/4.0/

c. (i) Open Access

\begin{abstract}
The aim of this study is the determination of a suitable solar radiation model for the twelve cities of Chad based on meteorological data. Three appropriate models are used to estimate the solar radiation of each site. The choice of these models is based on statistical tests such as the Root Mean Square Error (RMSE), the Mean Bias Error (MBE), the Mean Percentage Error (MPE), and the Nash-Sutcliffe Equation (NSE). The obtained results show that the Angstrom-Prescott model is the most suitable for the calculation of global solar radiation in the sites of Bongor, Pala, Am-timan and Mongo. For the sites of Moundou, Sarh and Bokoro the Allen model is the most adapted for the calculation of global solar radiation. On the other hand the Sabbagh model is the most appropriate for the sites of Faya-Largeau, Abeche, N'Djamena, Ati and Moussoro. It has been revealed that Abeche is the site with the highest solar radiation value equal to $6.354 \mathrm{kWh} / \mathrm{m}^{2}$ and Ati is the site where the solar radiation has the lowest value around $5.523 \mathrm{kWh} / \mathrm{m}^{2}$. Based on the obtained results, it is demonstrated that the three climatic zones of Chad have a good solar potential and consequently suitable for the exploitation of the solar energy systems.
\end{abstract}

\section{Keywords}

Global Solar Radiation, Sabbagh, Allen, Angstrom-Prescott, Meteorological Data 


\section{Introduction}

The energy sector of Chad, which is still weakly developed, is characterized by high consumption of wood fuels (wood and charcoal), which accounts for more than $90 \%$ of the total energy consumption of the country. The use of conventional energies (petroleum products and electricity) occupies a marginal part of the national energy balance. These energies, although crucial in the development of a modern economy, account for only about $10 \%$ of total energy consumption in the country. There is no interconnected network in the country. Chad, however, has significant energy potential such as hydrocarbons, biomass and renewable energies, including solar and wind energy, whose exploitation could have contributed to the development of the sector. Solar energy applications require, above all, knowledge of the global solar radiation of a site. Thus, a reliable estimation of global solar radiation for a site is fundamental. Doing this will allow adequate knowledge of how to channel such application for either electricity generation, water heating, or irrigation, to mention a few [1] [2] [3]. In a developing country, the data are recorded directly only in a few meteorological stations. In many stations, the spatial coverage of radio stations is insufficient. For example, in Chad, there is not only a lack of measuring equipment, but also of training technicians. In addition, lack of maintenance or calibration of solar radiation sensors gives erroneous measurements or missing data [4]. Researchers have developed a large number of methods to estimate global solar radiation due to lack of reliable data on solar radiation. These methods are based on an empirical model linking variables such as humidity [5] [6], temperature [7] [8] [9] [10], elevation [11] [12], duration of the sun [13] [14] [15] [16] and latitude [17] [18]. It may be easier to exploit solar energy resources when the site under consideration is equipped with a pyranometer functioning regularly for several years. However, there is need to use approximate methods to predict solar radiation characteristics if local measures do not exist. Numerous models have been developed that connect global solar radiation to extraterrestrial solar radiation in order to estimate the amount of solar energy incident on a horizontal surface. Among these models, the Angstrom-Prescott model has been developed and employed by many researchers and with certain meteorological parameters [19]. In the estimation of global solar radiation, each of these factors contributes significantly.

This study was therefore focused to develop a mathematical model to estimate the solar radiation coming from extraterrestrial radiation, with meteorological and geographical data as governing parameters. The model was validated by comparing its results with experimentally measured data across the twelve sites of Chad. The impact of this is the fact that such model can now be used to analyse and make informed decisions on solar technology applications without recourse to several years of experimental measurements around the studied sites and across the region. 


\section{Data Base}

Solar data employed for the study were obtained from the General directorate of the National Meteorology of Chad, in June 2014 covering the period of 63 years (i.e. 1950-2013). They are monthly data of the relative humidity, maximum temperature, minimal temperature, and sunshine duration. The geographical coordinates of the twelve stations of the National office of Meteorology (ONM) are given in Table 1.

\section{Used Models}

To calculate the global solar radiation, one has recourse to the ideal models. These models are in the form of empirical relations which connect the components of the solar radiation to the principal weather parameters and the astronomical parameters. The weather parameters are the ambient temperature, the relative humidity, the sunshine duration. Amongst the astronomical parameters one has the maximum duration of the day, the variation of the sun, the variation of the ground-sun distance and the solar radiation in the extraterrestrial radiation [20]. As part of this work, these include the Angstrom-Prescott model, the Allen model and the Sabbagh model.

\subsection{Estimation of Extraterrestrial Radiation, $\boldsymbol{H}_{0}$}

The monthly mean of the daily extraterrestrial solar radiation on a horizontal surface is determined according the following relation [21] [22] [23] [24] [25]:

$$
H_{0}=\frac{24}{\pi} I_{s c}\left[1+0.33 \cos \left(\frac{360 D_{n}}{365}\right)\right] *\left[\cos L \cos \delta \sin \omega_{s}+\frac{2 \pi \omega_{s}}{360} \sin L \sin \delta\right]
$$

Table 1Geographical locations of the sites considered.

\begin{tabular}{ccccc}
\hline Zones & sites & Latitude $\left({ }^{\circ} \mathrm{N}\right)$ & Longitude $\left({ }^{\circ} \mathrm{E}\right)$ & Elevation $(\mathrm{m})$ \\
\hline Saharan zone & Faya-Largeau & 17.55 & 19.7 & 233 \\
& Abeche & 13.51 & 20.51 & 545 \\
Sahelian zone & N'Djamena & 12.8 & 15.2 & 294 \\
& Ati & 13.13 & 18.19 & 334 \\
& Bokoro & 12.23 & 17.3 & 300 \\
& Mongo & 12.11 & 18.41 & 430 \\
& Moussoro & 13.39 & 16.3 & 301 \\
& Am-timan & 11.2 & 20.17 & 432 \\
& Bongor & 10.17 & 16.22 & 328 \\
& Moundou & 8.37 & 16.4 & 420 \\
Sudanese zone & Pala & 9.22 & 14.55 & 420 \\
& Sarh & 9.9 & 18.23 & 364 \\
\hline
\end{tabular}


where $\delta$ and $\omega_{s}$ are respectively the monthly mean of the daily solar declination and the sunshine hour angle defined by [26] [27] [28]:

$$
\begin{gathered}
\delta=23.45 \sin \left[\frac{360\left(284+D_{n}\right)}{365}\right] \\
\omega_{s}=\cos ^{-1}(-\tan L \tan \delta)
\end{gathered}
$$

where $I_{s c}$ is the solar constant $\left(I_{s c}=1367 \mathrm{~W} / \mathrm{m}^{2}\right), L$ is the location latitude, $D_{n}$ is the number of the day in the year.

\subsection{Global Solar Radiation on a Horizontal Level with Angstrom-Prescott Model}

Angstrom has been the first to propose an ideal model (linear model) to estimate the horizontal global solar radiation with in entry the data over the sunshine duration [29] [30] [31]. Prescott and Page [32] [33] have improved this model and considered the horizontal global solar radiation of the sunshine duration according to the relation (4).

$$
\frac{H}{H_{0}}=a+b\left(\frac{S}{S_{0}}\right)
$$

The parameters a, bare respectively defined by the Equations (5) and (6).

$$
\begin{gathered}
a=-0.110+0.235 \cos L+0.323\left(\frac{S}{S_{0}}\right) \\
b=1.449-0.553 \cos L-0.694\left(\frac{S}{S_{0}}\right)
\end{gathered}
$$

The possible maximum monthly mean of the daily sunshine duration is [34]:

$$
S_{0}=\frac{2}{15} \cos ^{-1}(-\tan L \tan \delta)
$$

\subsection{Global Solar Radiation on a Horizontal Level with the Allen Model}

Allen [35] [36] estimated the monthly mean of the global solar radiation as a function of $H_{0}$, the monthly mean of the maximum temperature $\left(T_{M}\right)$, and the monthly mean of the minimum temperature $\left(T_{m}\right)$ as:

$$
\frac{H}{H_{0}}=K_{r}\left(T_{M}-T_{m}\right)^{0.5}
$$

Where $K_{r}$ is defined as:

$$
K_{r}=K_{r a}\left(\frac{P}{P_{0}}\right)^{0.5}
$$

In the relation (9), $K_{r a}=0.17$ and $P / P_{0}$ may be defined as:

$$
\frac{P}{P_{0}}=\exp (-0.0001184 h)
$$


where $P$ and $P_{0}$ are respectively the values of local and standard atmospheric pressure, and $h$ is the altitude of the place in meters.

\subsection{Global Solar Radiation on a Horizontal Level with the Sabbagh Model}

While being based on data relating to several countries of the Gulf, in particular, the sites of Saudi Arabia, Sabbagh et al. developed two empirical relations binding the various weather parameters which affect the attenuation of the solar radiation, namely: sunshineduration, relative humidity, the maximum temperature, the altitude, the geographical situation (longitude, latitude) and its situation compared to the sea and a lake of water characterized by the characteristic factor of the zone, which is given by the following relation [37]:

$$
H=1.530 K * \exp L\left(\frac{S}{S_{0}}-\frac{R H^{1 / 3}}{100}-\frac{1}{T_{\max }}\right),
$$

With:

$$
\begin{gathered}
K=100\left(n T_{\max }+\psi_{i j} \cos (L)\right), \\
n=\frac{1}{(1+0.1 L)},
\end{gathered}
$$

$R H$ and $T_{\max }$ are respectively the monthly average per day of the sunshine duration, the relative humidity and the maximum average temperature of the considered month.

$\psi_{i j}$, climatic factor

$n$, number of the month considered

$S$, monthly average daily bright sunshine duration (h)

\section{Statistical Test}

In order to compare the data of the solar radiation provided by NASA (National Aeronautic and Space Administration) with those obtained from the various presented models, all the different models were implemented by creating a code using MATLAB and Excel.From each of these programs and for each studied site, on the one hand we drew up in the same graph, the values of whole-body radiation by NASA and those calculated, and in the other hand we drew up the relative error. The presented models in paragraph 3 permitted to evaluate the calculated global radiation $H_{i, c}$ in order to be compared to the measured global radiation $H_{i, m}$.

Several statistical indicators used in the literature [20] [21] [37]-[42] were employed to determine the degree of accuracy of the estimated values as compared to measured values. These indicators included:RMSE, MBE, MPE and NSE.

$R M S E$ (Root Mean Square Errors) is a measure of the variation of calculated values; it gives information about the performance of the model and is always positive values. The model is best when its RMSE value is the smallest. It is de- 
fined by the relation:

$$
R M S E=\sqrt{\sum_{i=1}^{n} \frac{\left(H_{i, c}-H_{i, m}\right)^{2}}{n}}
$$

$n$ is the number of the month.

The mean bias error $(M B E)$ is the mean inclination error giving information on the performance of the long-term model. To this end, a negative value refers to underestimation, while positive value refers to an overestimation. It is given by Equation (15):

$$
M B E=\sum_{i=1}^{n} \frac{\left(H_{i, c}-H_{i, m}\right)}{n}
$$

The MPE (Mean Percentage Error) is defined by the relation:

$$
\operatorname{MPE}(\%)=\frac{1}{n} * \sum_{i=1}^{n} \frac{\left(H_{i, c}-H_{i, m}\right)}{H_{i m}} * 100
$$

For this indicator, for a given model, an error expressed as a percentage between $-10 \%$ and $+10 \%$ is acceptable.

The NSE (Nash-Sutcliffe Equation) represents a measure of the precision of the model results. The NSE is defined by the relation:

$$
N S E=1-\frac{\sum_{i=1}^{n}\left(H_{i, m}-H_{i, c}\right)^{2}}{\sum_{i=1}^{n}\left(H_{i, m}-\bar{H}_{m}\right)^{2}}
$$

where: $\bar{H}_{m}$ is the mean measured global radiation.

\section{Results and Discussions}

To estimate the overall solar radiation using the Angstrom-Prescott model, apart from the geographical coordinates of the site, the average daily insolation duration was considered.

Meteorological data such as relative humidity, maximum temperature and average daily sun exposure measured the overall solar radiation using the Sabbagh model. Maximum temperature and minimum temperature were considered in the Allen model.

Figure 1 presents the map of Chad with the three climatic zones. The different sites that make up these areas can be observed.

Figure 2 presents the results of the monthly extraterrestrial radiation for the twelve sites in the three climatic zones of Chad. It can be noted in this table that the smallest value of the extraterrestrial radiation of $8.112 \mathrm{kWh} / \mathrm{m}^{2}$ is found in Faya-Largeau. The highest value of $9.364 \mathrm{kWh} / \mathrm{m}^{2}$ is found at Moundou.

Figure 3 presents the values of the monthly global solar radiation in the form of histograms obtained through the three appropriate models of estimation for each studied site.

Tables 2-5 present the total results obtained through the relations of Angstrom-Prescott, Allen, Sabbagh equation and Sabbagh model for the twelve sites of the three climatic zones of Chad. 


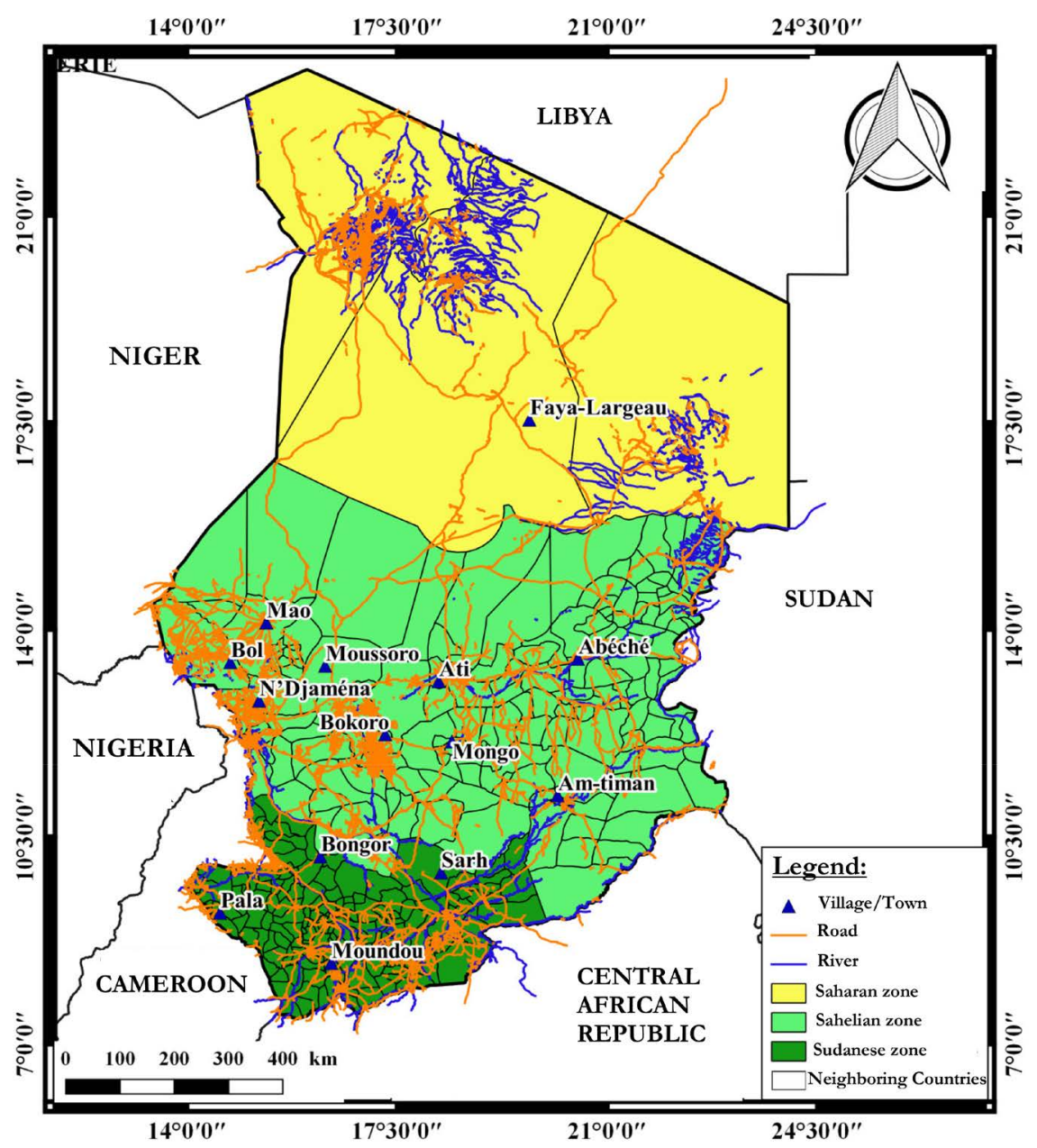

Figure 1. Presentation of the map of Chad with the three climatic zones.

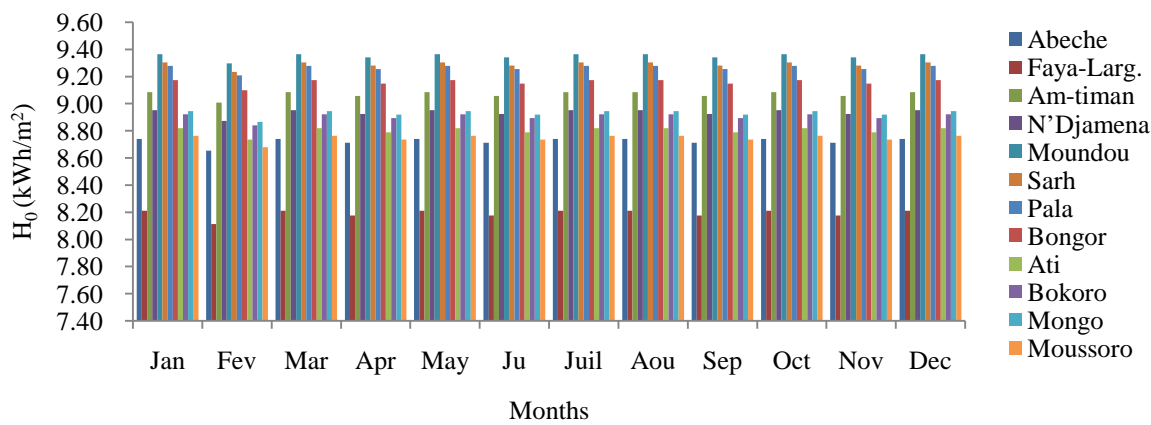

Figure 2. Monthly extraterrestrial solar radiation.

In Table 2 the values of the various parameters of Angstrom-Prescott model for the twelve sites of the three climatic zones of Chad are presented. Thus based on Angstrom-Prescott model calculation, one can conclude that Am-timan is the suitable place for the exploitation of solar energy compared to the other sites, because of his highest monthly global solar radiation of $5.917 \mathrm{kWh} / \mathrm{m}^{2}$. The smallest value of the monthly global solar radiation calculated through Angstrom-Prescott model is $5.457 \mathrm{kWh} / \mathrm{m}^{2}$ (obtained for the site of Faya-Largeau). 


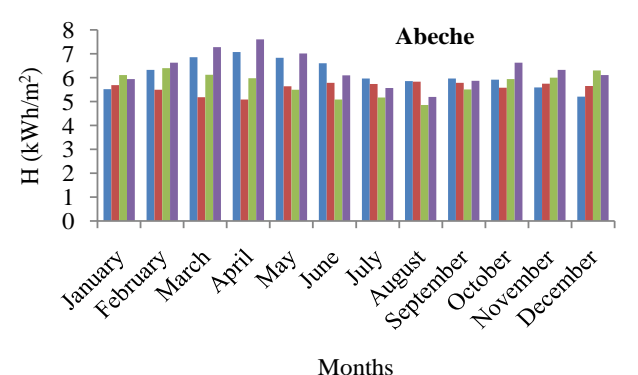

(a)

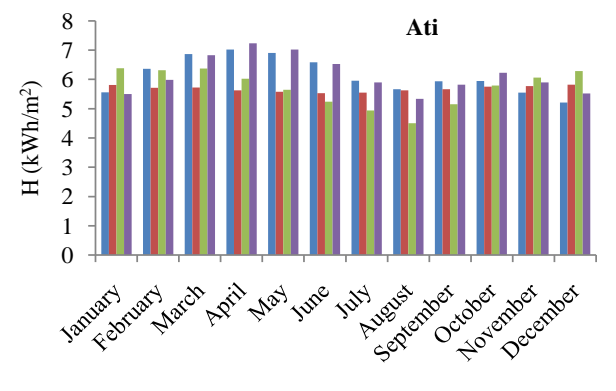

(c)

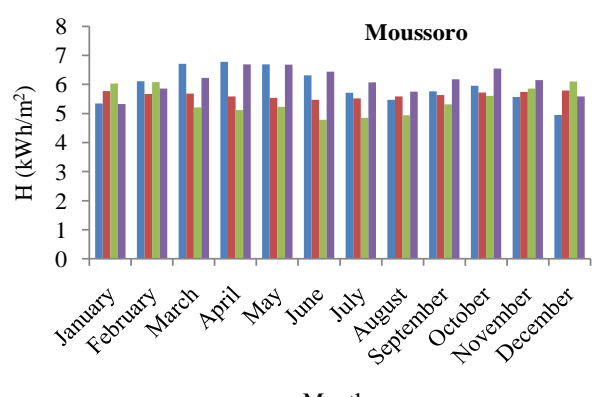

(e)

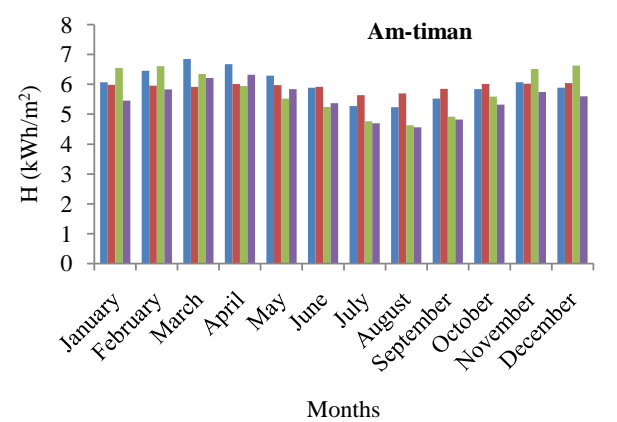

(g)

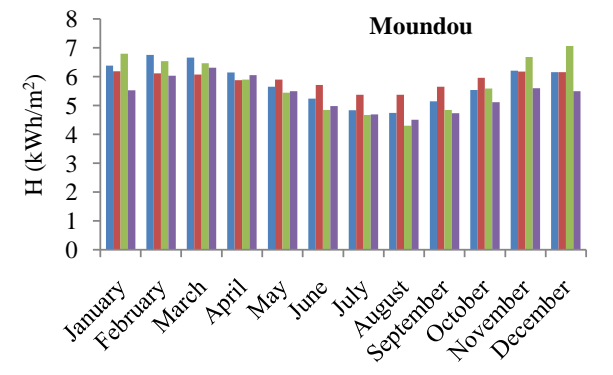

Months

(i)

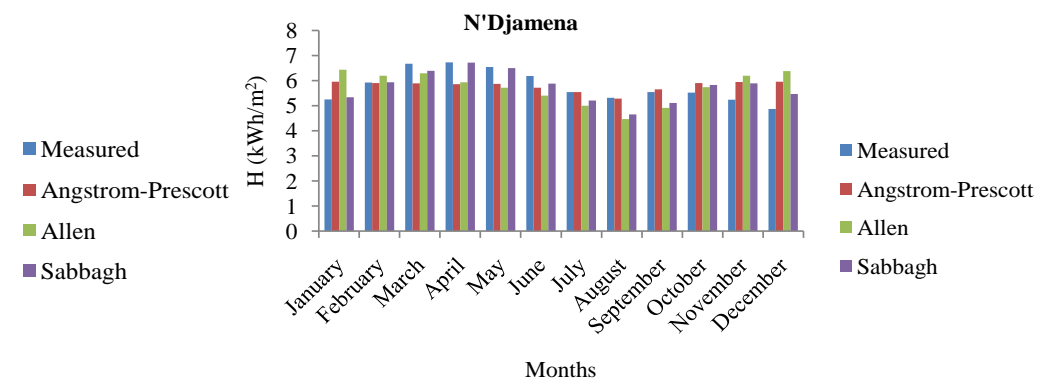

(b)

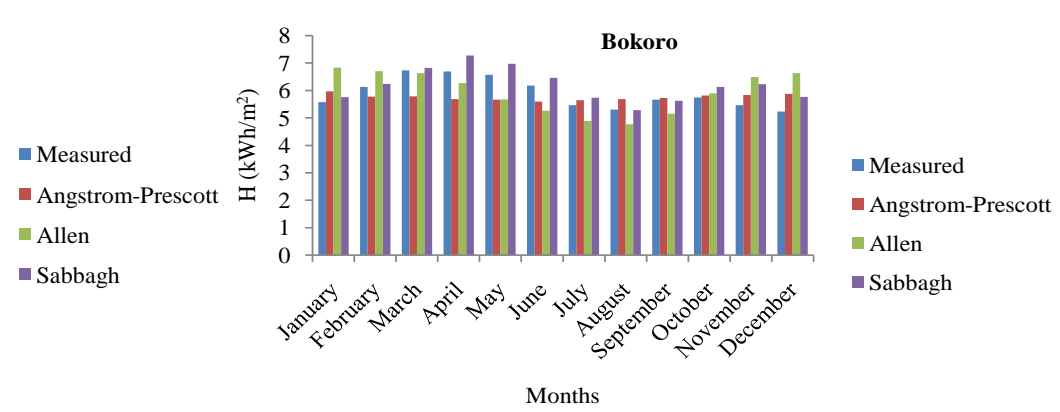

(d)

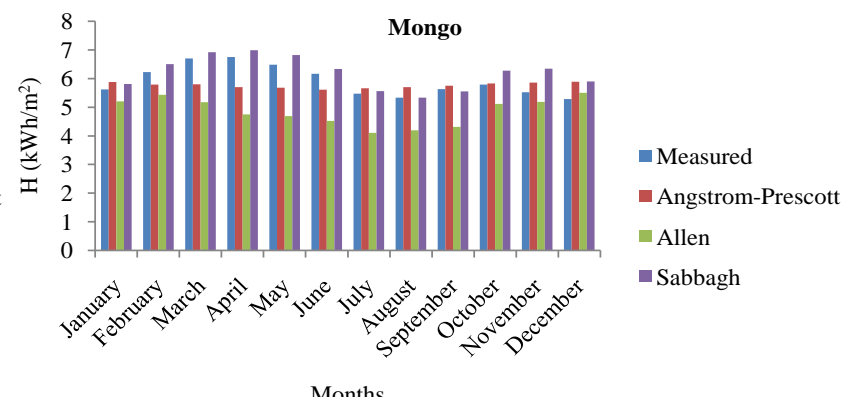

(f)

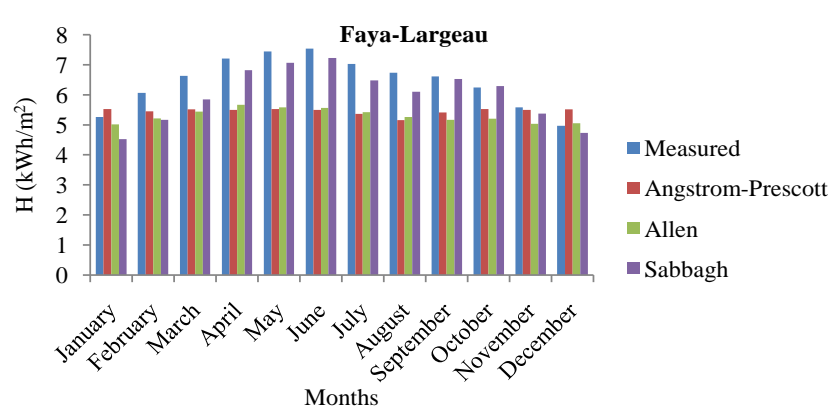

(h)

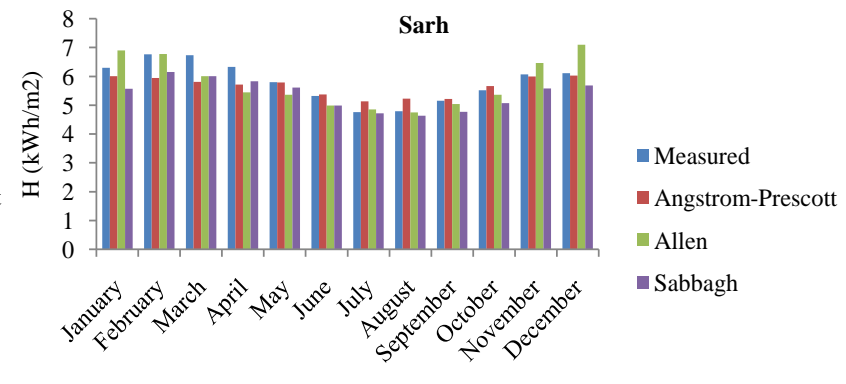

Months

(j) 


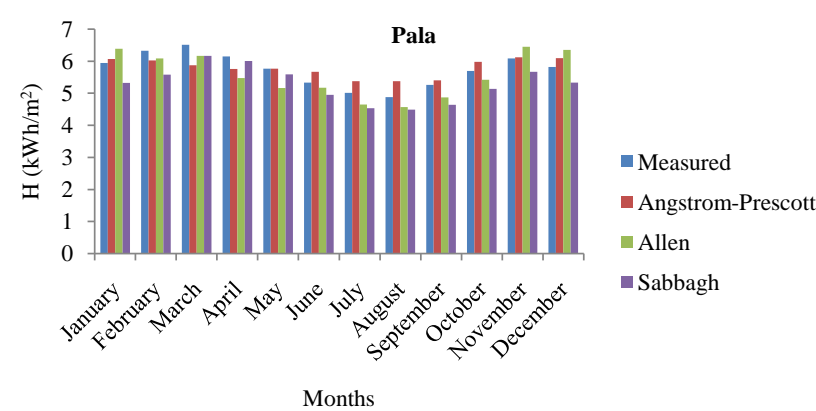

(k)

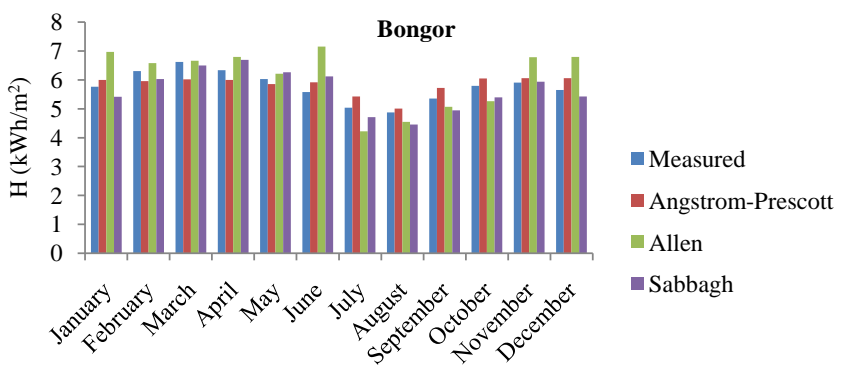

Months

Figure 3. Monthly global solar radiation of the twelve sites.

Table 2. Angstrom-Prescott model for the twelve sites.

\begin{tabular}{|c|c|c|c|c|c|c|c|c|c|}
\hline Sites & $a$ & $b$ & $H_{0}$ & $S(h)$ & $S_{0}(h)$ & $H / H_{0}$ & $S / S_{0}$ & $H\left(\mathrm{kWh} / \mathrm{m}^{2}\right)$ & $\operatorname{Err}(\%)$ \\
\hline Faya-Largeau & 0.39 & 0.33 & 8.19 & 9.59 & 11.2 & 0.67 & 0.86 & 5.457 & -13.791 \\
\hline Abeche & 0.45 & 0.2 & 8.722 & 11.62 & 11.39 & 0.64 & 1.02 & 5.600 & -7.807 \\
\hline Am-timan & 0.37 & 0.36 & 9.069 & 8.97 & 11.52 & 0.65 & 0.78 & 5.917 & -0.887 \\
\hline N’Djamena & 0.37 & 0.38 & 8.936 & 8.74 & 11.47 & 0.65 & 0.76 & 5.791 & 1.265 \\
\hline Bongor & 0.35 & 0.41 & 9.158 & 8.3 & 11.55 & 0.64 & 0.72 & 5.839 & 1.590 \\
\hline Moundou & 0.34 & 0.43 & 9.351 & 7.97 & 11.62 & 0.63 & 0.68 & 5.88 & 1.482 \\
\hline Pala & 0.34 & 0.44 & 9.265 & 7.77 & 11.59 & 0.62 & 0.67 & 5.792 & 2.454 \\
\hline Sarh & 0.32 & 0.47 & 9.29 & 7.17 & 11.6 & 0.61 & 0.62 & 5.658 & -1.765 \\
\hline Ati & 0.46 & 0.18 & 8.802 & 12.09 & 11.42 & 0.65 & 1.06 & 5.681 & -6.446 \\
\hline Bokoro & 0.46 & 0.18 & 8.905 & 12.08 & 11.46 & 0.65 & 1.05 & 5.748 & -1.547 \\
\hline Mongo & 0.46 & 0.18 & 8.93 & 12.09 & 11.47 & 0.65 & 1.05 & 5.763 & -1.829 \\
\hline Moussoro & 0.46 & 0.17 & 8.748 & 12.1 & 11.4 & 0.65 & 1.06 & 5.646 & 3.400 \\
\hline
\end{tabular}

Table 3. Allen model for the twelve sites.

\begin{tabular}{|c|c|c|c|c|c|c|}
\hline Sites & $T_{M}$ & $T_{\min }\left({ }^{\circ} \mathrm{C}\right)$ & $H_{0}$ & $H / H_{0}$ & $H\left(\mathrm{kWh} / \mathrm{m}^{2}\right)$ & Err (\%) \\
\hline Faya-Largeau & 35.65 & 21.13 & 8.19 & 0.65 & 5.3 & -16.723 \\
\hline Abeche & 37.42 & 22.28 & 8.722 & 0.66 & 5.747 & -5.482 \\
\hline Am-timan & 34.78 & 20.54 & 9.069 & 0.64 & 5.771 & -3.958 \\
\hline N’Djaména & 36.38 & 22.02 & 8.936 & 0.64 & 5.724 & 0.078 \\
\hline Bongor & 36.42 & 20.74 & 9.158 & 0.665 & 6.085 & 5.154 \\
\hline Moundou & 34.525 & 21.066 & 9.351 & 0.616 & 5.76 & -3.074 \\
\hline Pala & 33.925 & 21.266 & 9.265 & 0.601 & 5.563 & -0.844 \\
\hline Sarh & 35.083 & 21.55 & 9.29 & 0.619 & 5.751 & -0.878 \\
\hline Ati & 36.22 & 21.41 & 8.802 & 0.651 & 5.726 & -5.825 \\
\hline Bokoro & 36.73 & 21.13 & 8.905 & 0.666 & 5.932 & 1.181 \\
\hline Moussoro & 35.56 & 22.13 & 8.748 & 0.621 & 5.429 & -7.523 \\
\hline
\end{tabular}

The Angstrom-Prescott model is the most suitable for the calculation of global solar radiation based on the relative error with NASA data especially for the sites: Bongor (1.590\%), Pala (1.482\%), Am-timan (-0.887\%) and Mongo (-1.829\%). 
Table 4. Sabbagh equations model for the twelve sites.

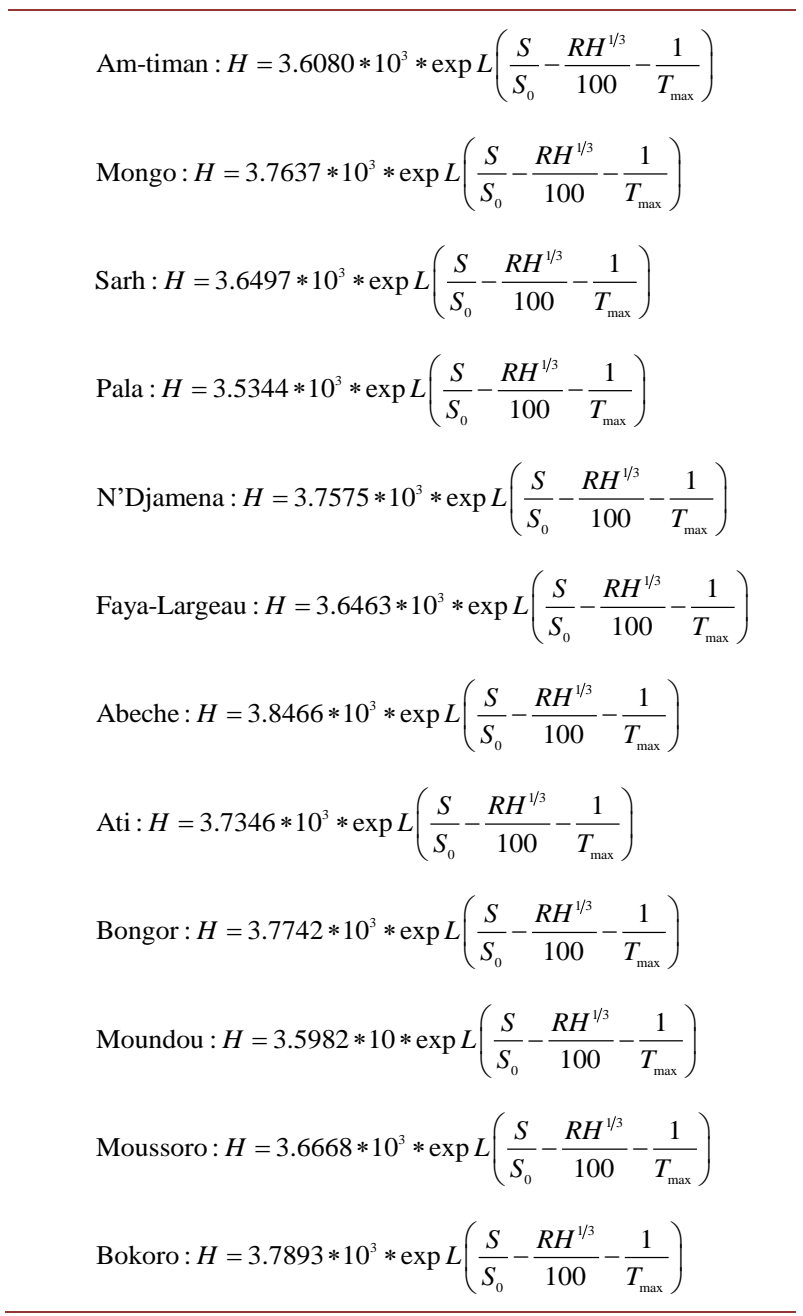

Table 5. Sabbagh model for the twelve sites.

\begin{tabular}{cccccccc}
\hline Sites & $S$ & $S_{0}(\mathrm{~h})$ & $R H(\%)$ & $T_{\max }\left({ }^{\circ} \mathrm{C}\right)$ & $S / S_{0}$ & $H\left(\mathrm{kWh} / \mathrm{m}^{2}\right)$ & Err $(\%)$ \\
\hline Faya-Largeau & 9.59 & 11.2 & 20.37 & 35.65 & 0.857 & 6.013 & -6.766 \\
Abeche & 11.62 & 11.39 & 36 & 37.42 & 1.02 & 6.354 & 3.704 \\
Am-timan & 8.74 & 11.47 & 44.85 & 36.38 & 0.76 & 5.742 & -8.837 \\
N'Djamena & 8.74 & 11.47 & 44.85 & 36.38 & 0.76 & 5.742 & -0.348 \\
Bongor & 8.3 & 11.55 & 56.83 & 36.42 & 0.72 & 5.656 & -2.162 \\
Moundou & 7.97 & 11.62 & 59.09 & 34.52 & 0.68 & 5.377 & -7.879 \\
Pala & 7.76 & 11.59 & 52.93 & 33.92 & 0.67 & 5.285 & -6.892 \\
Sarh & 7.17 & 11.6 & 59.31 & 35.08 & 0.62 & 5.385 & -6.946 \\
Ati & 12.09 & 11.42 & 39.52 & 36.22 & 1.06 & 6.151 & 0.356 \\
Bokoro & 12.08 & 11.46 & 42.13 & 36.73 & 1.05 & 6.189 & 5.032 \\
Mongo & 12.09 & 11.47 & 36.37 & 36.45 & 1.05 & 6.195 & 4.825 \\
Moussoro & 12.1 & 11.4 & 33.18 & 35.56 & 1.06 & 6.126 & 3.4 \\
\hline
\end{tabular}


Table 3 presents the estimation of the global solar radiation through the relation of Allen shows that it is Bongor which has the best solar potential with a value of $6.085 \mathrm{kWh} / \mathrm{m}^{2}$, compared to the other sites of Chad.On the other hand, one notices that in term of relative error with measured data, the Allen model is more adapted for the calculation of the global solar radiation of N'Djamena, Pala and Sarh, respectively with a mean relative error of $0.078 \%, 0.844 \%$ and $0.878 \%$.Moreover, Abeche is the site where the temperature is the highest with a value of $37.42^{\circ} \mathrm{C}$ while the lowest temperature is $20.54^{\circ} \mathrm{C}$ (in the site of Am-timan).

Table 4 presents the obtained values of the Sabbagh equations for the twelve sites of Chad. Thus, we note in this table the variation of the coefficients which is of the order of $3.5344 * 10^{3}$ to Pala and $3.8466 * 10^{3}$ to Abeche.

Table 5 presents the obtained values of the parameters of Sabbagh model for the twelve sites of Chad. Abeche is the site where the sunshine duration is the highest (11.62 h); the smallest value is observed in Sarh $(7.17 \mathrm{~h})$.The highest value of the duration of the day is noted in Moundou (11.62 h) while the lowest value is observed in Faya-Largeau (11.20 h).For the relative humidity, it is in Sarh which has the highest value (59.31\%); the smallest value is observed in Faya-Largeau (20.37\%). In addition, the highest value of the maximum temperature is observed in Abeche $\left(37.42^{\circ} \mathrm{C}\right)$ and the lowest value is observed in Pala $\left(33.92^{\circ} \mathrm{C}\right)$.The highest valueof sunshine rate is observed in Abeche (1.02) and the lowest value is observed in Sarh (0.62).The estimation of the global solar radiation for all sites through Sabbagh model shows that the highest value is observed in Abeche $\left(6.354 \mathrm{kWh} / \mathrm{m}^{2}\right)$ and the lowest value is observed in Pala (5.285 $\mathrm{kWh} / \mathrm{m}^{2}$ ). The various results show indeed that the three zones of Chad do not have the same climatic conditions.

The Sabbagh model is the most suitable for calculating global radiation based on the relative error with NASA data especially for the sites: Faya-Largeau (-6.766\%), Abeche (3.704\%), N'Djamena (-0.348\%), Ati (0.356\%) and Moussoro $(3.400 \%)$.

It can also be noted that all three models can only be applied if weather data and geographic parameters are available for a given site. The reliability of these models is the correct estimate of global solar radiation without going through direct and diffuse radiation. Moreover, it is observed that the solar radiation is affected by the meteorological parameters because the decrease of the parameters such as the temperature and the relative humidity leads to the reduction of the solar radiation. For example, the month of August seems the most unfavorable because the more it rains, the more radiation decreases.

Table 6 compares the three models used for the twelve studied sites. The comparison between the obtained results through the three models of calculation and the measured data shows that the Angstrom-Prescott model gives the best estimation of the global solar radiation for the sites of Bongor $(M P E(\%)=$ 1.5902; $R M S E=0.3368 ; M B E=0.0159 ; N S E=0.6999)$, Pala $(M P E(\%)=1.4822$; $R M S E=0.3338 ; M B E=0.0148 ; N S E=0.7241), A m-\operatorname{timan}(M P E(\%)=-0.8875 ;$ 
Table 6. Statistics for the validation of the selected models $\left(\mathrm{kWh} / \mathrm{m}^{2}\right)$.

(a)

\begin{tabular}{ccccc}
\hline \multicolumn{5}{c}{ Angstrom-Prescott } \\
\hline Sites & $M P E(\%)$ & $R M S E\left(\mathrm{kWh} / \mathrm{m}^{2}\right)$ & $M B E\left(\mathrm{kWh} / \mathrm{m}^{2}\right)$ & $N S E\left(\mathrm{kWh} / \mathrm{m}^{2}\right)$ \\
\hline Abeche & -7.8073 & 0.9141 & -0.0781 & -1.5902 \\
Faya-Largeau & -13.791 & 1.289 & -0.1379 & -1.2293 \\
Am-timan & -0.8875 & 0.4256 & -0.0089 & 0.291 \\
N'Djamena & 1.2655 & 0.6038 & 0.0127 & 0.2408 \\
Moundou & 2.4541 & 0.4353 & 0.0245 & 0.6596 \\
Sarh & -1.7654 & 0.4417 & -0.0177 & 0.6453 \\
Pala & 1.4822 & 0.3338 & 0.0148 & 0.7241 \\
Bongor & 1.5902 & 0.3368 & 0.0159 & 0.6999 \\
Ati & -6.4463 & 0.7823 & -0.0645 & -0.8224 \\
Bokoro & -1.5466 & 0.5834 & -0.0155 & -0.0377 \\
Mongo & -1.8291 & 0.5609 & -0.0183 & -0.0373 \\
Moussoro & -4.1310 & 0.6887 & -0.0413 & -0.3560 \\
\hline
\end{tabular}

(b)

\begin{tabular}{ccccc}
\hline \multicolumn{5}{c}{ Allen } \\
\hline Sites & $M P E(\%)$ & $R M S E\left(\mathrm{kWh} / \mathrm{m}^{2}\right)$ & $M B E\left(\mathrm{kWh} / \mathrm{m}^{2}\right)$ & $N S E\left(\mathrm{kWh} / \mathrm{m}^{2}\right)$ \\
\hline Abeche & -5.4824 & 0.8835 & -0.0548 & -1.4197 \\
Faya-Largeau & -16.724 & 1.297 & -0.1672 & -1.256 \\
Am-timan & -3.9584 & 0.5638 & -0.0396 & -0.2442 \\
N’Djamena & 0.0784 & 0.8275 & 0.0008 & -0.4261 \\
Moundou & -0.8437 & 0.3962 & -0.0084 & 0.7181 \\
Sarh & -0.8779 & 0.5114 & -0.0088 & 0.5245 \\
Pala & -3.0737 & 0.4175 & -0.0307 & 0.5684 \\
Bongor & 5.1543 & 0.7879 & 0.0515 & -0.6421 \\
Ati & -5.8254 & 0.9031 & -0.0583 & -1.4289 \\
Bokoro & 1.1811 & 0.799 & 0.0118 & -0.9464 \\
Mongo & -17.506 & 1.2438 & -0.1751 & -4.1008 \\
Moussoro & -7.523 & 1.0278 & -0.0752 & -2.0198 \\
\hline
\end{tabular}

(c)

\begin{tabular}{ccccc}
\hline \multicolumn{5}{c}{ Sabbagh } \\
\hline Sites & $M P E(\%)$ & $R M S E\left(\mathrm{kWh} / \mathrm{m}^{2}\right)$ & $M B E\left(\mathrm{kWh} / \mathrm{m}^{2}\right)$ & $N S E\left(\mathrm{kWh} / \mathrm{m}^{2}\right)$ \\
\hline Abeche & 3.7042 & 0.5418 & 0.037 & 0.0899 \\
Faya-Largeau & -6.7662 & 0.513 & -0.0677 & 0.6468 \\
Am-timan & -8.8376 & 0.5406 & -0.0884 & -0.1439 \\
N'Djamena & -0.3477 & 0.3842 & -0.0035 & 0.6927 \\
Moundou & -6.8922 & 0.475 & -0.0689 & 0.5949 \\
Sarh & -6.9461 & 0.4677 & -0.0695 & 0.6023 \\
Pala & -7.8795 & 0.4787 & -0.0788 & 0.4327 \\
Bongor & -2.1625 & 0.3344 & -0.0216 & 0.7042 \\
Ati & 0.3564 & 0.2314 & 0.0036 & 0.84056 \\
Bokoro & 5.0317 & 0.3798 & 0.0503 & 0.5602 \\
Mongo & 4.8254 & 0.3722 & 0.0483 & 0.5432 \\
Moussoro & 3.4003 & 0.3879 & 0.034 & 0.5697 \\
\hline
\end{tabular}


Table 7. Comparison between measured and estimated monthly global solar radiation $\left(\mathrm{kWh} / \mathrm{m}^{2}\right)$. (a) Site of Abeche; (b) site of Faya-Largeau; (c) site of Am-timan; (d) site of N'Djamena; (e) site of Moundou; (f) site of Sarh; (g) site of Pala; (h) site of Bongor; (i) site of Ati; (j) site of Bokoro; (k) site of Mongo; (l) site of Moussoro.

(a)

\begin{tabular}{cccc}
\hline Month & Angstrom-Prescott Err (\%) & Allen Err (\%) & Sabbagh Err (\%) \\
\hline January & 3.080 & 10.634 & 7.663 \\
February & -13.117 & 1.203 & 4.810 \\
March & -24.563 & -10.714 & 6.064 \\
April & -28.133 & -15.446 & 7.581 \\
May & -17.467 & -19.488 & 2.635 \\
June & -12.379 & -22.939 & -7.667 \\
July & -3.725 & -13.289 & -6.577 \\
August & -0.478 & -17.065 & -11.451 \\
September & -2.886 & -7.701 & -1.493 \\
October & -5.668 & 0.541 & 12.200 \\
November & 2.898 & 7.263 & 13.184 \\
December & 8.750 & 21.212 & 17.500 \\
Average & -7.807 & -5.482 & 3.704 \\
\hline
\end{tabular}

(b)

\begin{tabular}{cccc}
\hline Month & Angstrom-Presott Err (\%) & Allen Err (\%) & Sabbagh Err (\%) \\
\hline January & 4.981 & -4.696 & -14.049 \\
February & -10.066 & -13.944 & -14.802 \\
March & -16.757 & -17.934 & -11.84 \\
April & -23.745 & -21.456 & -5.409 \\
May & -25.766 & -24.973 & -5.040 \\
June & -27.056 & -26.26 & -4.164 \\
July & -23.684 & -22.859 & -7.781 \\
August & -23.314 & -21.857 & -9.331 \\
September & -18.124 & -21.876 & -1.256 \\
October & -11.506 & -16.619 & 0.865 \\
November & -1.523 & -9.839 & -3.638 \\
December & 11.066 & 1.630 & -4.748 \\
Average & -13.791 & -16.724 & -6.766 \\
\hline
\end{tabular}

(c)

\begin{tabular}{cccc}
\hline Month & Angstrom-Prescott Err (\%) & Allen Err (\%) & Sabbagh Err (\%) \\
\hline January & -1.433 & 7.941 & -10.148 \\
February & -7.705 & 2.388 & -9.643 \\
March & -13.606 & -7.328 & -9.358 \\
April & -9.865 & -10.885 & -5.277 \\
May & -5.056 & -12.162 & -7.138 \\
June & 0.458 & -10.951 & -8.829 \\
July & 7.021 & -9.677 & -10.911 \\
August & 8.853 & -11.415 & -12.83 \\
September & 6.033 & -10.906 & -12.736 \\
October & 2.911 & -4.298 & -8.870 \\
November & -0.807 & 7.331 & -5.371 \\
December & 2.547 & 12.462 & -4.941 \\
Average & -0.887 & -3.958 & -8.838 \\
\hline
\end{tabular}


(d)

\begin{tabular}{cccc}
\hline Month & Angstrom-Prescot Err (\%) & Allen Err (\%) & Sabbagh Err (\%) \\
\hline January & 13.41 & 22.629 & 1.562 \\
February & -0.372 & 4.730 & 0.186 \\
March & -11.604 & -5.652 & -4.183 \\
April & -13.001 & -11.828 & -0.208 \\
May & -10.214 & -12.63 & -0.673 \\
June & -7.577 & -12.649 & -4.943 \\
July & 0.054 & -9.729 & -5.975 \\
August & -0.414 & -15.951 & -12.373 \\
September & 2.094 & -11.264 & -7.69 \\
October & 6.993 & 3.877 & 5.543 \\
November & 13.416 & 18.321 & 12.405 \\
December & 22.402 & 31.088 & 12.177 \\
Average & 1.265 & 0.078 & -0.348 \\
\hline
\end{tabular}

(e)

\begin{tabular}{cccc}
\hline Month & Angstrom-Prescott Err (\%) & Allen Err (\%) & Sabbagh Err (\%) \\
\hline January & -3.103 & 6.442 & -13.401 \\
February & -9.452 & -3.185 & -10.681 \\
March & -8.754 & -2.913 & -5.300 \\
April & -4.235 & -3.925 & -1.482 \\
May & 4.319 & -3.628 & -2.690 \\
June & 9.065 & -7.576 & -5.019 \\
July & 11.074 & -3.554 & -3.079 \\
August & 13.418 & -9.262 & -4.873 \\
September & 9.981 & -5.778 & -7.918 \\
October & 7.635 & 0.776 & -7.708 \\
November & -0.58 & 7.585 & -9.871 \\
December & 0.081 & 14.894 & -10.683 \\
Average & 2.454 & -0.844 & -6.892 \\
\hline
\end{tabular}

(f)

\begin{tabular}{cccc}
\hline Month & Angstrom-Prescott Err (\%) & Allen Err (\%) & Sabbagh Err (\%) \\
\hline January & -4.619 & 9.429 & -11.667 \\
February & -12.012 & 0.148 & -9.068 \\
March & -13.67 & -10.817 & -10.758 \\
April & -9.747 & -14.028 & -7.899 \\
May & -0.293 & -7.534 & -3.224 \\
June & 1.015 & -6.222 & -6.241 \\
July & 7.899 & 1.870 & -0.819 \\
August & 9.040 & -0.939 & -3.173 \\
September & 1.184 & -2.175 & -7.359 \\
October & 2.645 & -2.844 & -8.134 \\
November & -1.252 & 6.524 & -8.023 \\
December & -1.375 & 16.056 & -6.989 \\
Average & -1.765 & -0.878 & -6.946 \\
\hline
\end{tabular}


(g)

\begin{tabular}{cccc}
\hline Month & Angstrom-Prescott Err (\%) & Allen Err (\%) & Sabbagh Err (\%) \\
\hline January & 2.205 & 7.542 & -10.337 \\
February & -4.787 & -3.902 & -11.801 \\
March & -9.800 & -5.223 & -5.330 \\
April & -6.407 & -11.008 & -2.358 \\
May & 0.000 & -10.572 & -3.085 \\
June & 6.398 & -3.002 & -7.167 \\
July & 7.265 & -7.126 & -9.541 \\
August & 10.123 & -6.311 & -8.012 \\
September & 2.662 & -7.319 & -11.73 \\
October & 4.860 & -4.947 & -9.877 \\
November & 0.542 & 5.895 & -6.880 \\
December & 4.725 & 9.089 & -8.436 \\
Average & 1.482 & -3.073 & -7.879 \\
\hline
\end{tabular}

(h)

\begin{tabular}{cccc}
\hline Month & Angstrom-Prescott Err (\%) & Allen Err (\%) & Sabbagh Err (\%) \\
\hline January & 4.184 & 20.972 & -6.024 \\
February & -5.381 & 4.397 & -4.397 \\
March & -9.154 & 0.619 & -1.888 \\
April & -5.276 & 7.283 & 5.703 \\
May & -2.985 & 2.952 & 3.947 \\
June & 6.093 & 28.100 & 9.677 \\
July & 7.579 & -16.349 & -6.528 \\
August & 2.731 & -6.715 & -8.501 \\
September & 6.972 & -5.271 & -7.645 \\
October & 4.542 & -9.119 & -6.753 \\
November & 2.538 & 14.805 & 0.423 \\
December & 7.239 & 20.177 & -3.965 \\
Average & 1.590 & 5.154 & -2.162 \\
\hline
\end{tabular}

(i)

\begin{tabular}{cccc}
\hline Month & Angstrom-Prescott Err (\%) & Allen Err (\%) & Sabbagh Err (\%) \\
\hline January & 4.478 & 14.712 & -1.007 \\
February & -10.204 & -0.692 & -5.881 \\
March & -16.710 & -7.263 & -0.582 \\
April & -19.872 & -14.188 & 3.091 \\
May & -19.276 & -18.22 & 1.563 \\
June & -16.039 & -20.470 & -0.926 \\
July & -6.829 & -17.148 & -1.074 \\
August & -0.811 & -20.635 & -5.961 \\
September & -4.613 & -13.249 & -2.054 \\
October & -3.277 & -2.588 & 4.739 \\
November & 4.090 & 9.261 & 6.360 \\
December & 11.708 & 20.576 & 6.008 \\
Average & -6.446 & -5.825 & 0.356 \\
\hline
\end{tabular}


(j)

\begin{tabular}{cccc}
\hline Month & Angstrom-Prescott Err (\%) & Allen Err (\%) & Sabbag hErr (\%) \\
\hline January & 7.217 & 22.675 & 3.303 \\
February & -5.759 & 9.364 & 1.811 \\
March & -14.027 & -1.516 & 1.322 \\
April & -14.948 & -6.278 & 8.685 \\
May & -13.775 & -13.623 & 6.088 \\
June & -9.417 & -14.903 & 4.531 \\
July & 3.333 & -10.421 & 4.963 \\
August & 7.321 & -9.962 & -0.415 \\
September & 1.058 & -9.171 & -0.847 \\
October & 1.183 & 2.487 & 6.609 \\
November & 6.978 & 18.791 & 14.158 \\
December & 12.275 & 26.73 & 10.172 \\
Average & -1.547 & 1.181 & 5.032 \\
\hline
\end{tabular}

(k)

\begin{tabular}{cccc}
\hline Month & Angstrom-Prescott Err (\%) & Allen Err (\%) & Sabbagh Err (\%) \\
\hline January & 4.537 & -7.438 & 3.292 \\
February & -7.030 & -12.777 & 4.462 \\
March & -13.418 & -22.701 & 3.269 \\
April & -15.481 & -29.689 & 3.481 \\
May & -12.33 & -27.670 & 5.216 \\
June & -9.011 & -26.694 & 2.707 \\
July & 3.419 & -24.881 & 1.682 \\
August & 6.998 & -21.351 & 0.150 \\
September & 2.043 & -23.357 & -1.314 \\
October & 0.743 & -11.710 & 8.325 \\
November & 6.087 & -6.051 & 14.855 \\
December & 11.496 & 4.242 & 11.780 \\
Average & -1.829 & -17.506 & 4.825 \\
\hline
\end{tabular}

(1)

\begin{tabular}{cccc}
\hline Month & Angstrom-Prescott Err (\%) & Allen Err (\%) & Sabbagh Err (\%) \\
\hline January & 7.963 & 12.822 & -0.430 \\
February & -7.087 & -0.491 & -4.157 \\
March & -15.216 & -22.28 & -7.258 \\
April & -15.537 & -24.469 & -1.283 \\
May & -17.130 & -21.794 & -0.179 \\
June & -13.249 & -24.216 & 2.076 \\
July & -3.327 & -15.079 & 6.375 \\
August & 2.194 & -9.744 & 5.229 \\
September & -2.222 & -7.622 & 7.257 \\
October & -3.993 & -5.872 & 9.899 \\
November & 3.124 & 5.135 & 10.467 \\
December & 16.909 & 23.333 & 12.808 \\
Average & -4.131 & -7.523 & 3.400 \\
\hline
\end{tabular}


$R M S E=0.4256 ; M B E=-0.0089 ; N S E=0.291)$ and Mongo $(M P E(\%)=-1.8291 ;$ $R M S E=0.5609 ; M B E=-0.0183 ; N S E=-0.0373)$.

The Allen model is appropriate for Moundou $(M P E(\%)=-0.8437 ; R M S E=$ $0.3962 ; M B E=-0.0084 ; N S E=0.7181)$, Sarh $(M P E(\%)=-0.8779 ; R M S E=$ $0.5114 ; M B E=-0.0088 ; N S E=0.5245)$ and Bokoro $(M P E(\%)=1.1811 ; R M S E=$ $0.799 ; M B E=0.0118 ; N S E=-0.9464)$. For the cities of Faya-Largeau $(M P E(\%)=$ -6.7662; RMSE $=0.513 ; M B E=-0.0677 ; N S E=0.6468)$, Abeche $(M P E(\%)=$ $3.7042 ; R M S E=0.5418 ; M B E=0.037 ; N S E=0.0899), N^{\prime} D j a m e n a(M P E(\%)=$ $-0.3477 ; R M S E=0.3842 ; M B E=-0.0035 ; N S E=0.6927)$, Ati $(M P E(\%)=$ $0.3564 ; R M S E=0.2314 ; M B E=0.034 ; N S E=0.5697)$ and Moussoro $(M P E(\%)=$ 3.4003; RMSE $=0.3879 ; M B E=-0.0677 ; N S E=0.6468)$, it is the Sabbagh model which is adapted for the calculation of the global solar radiation.

We can justify that one model is more suitable than another if the statistical values tend towards zero.

The Comparison between the measureddataandthe estimated values of the monthly global solar radiation is presented in Table 7 .

\section{Conclusions}

In this work, the most adapted mathematical model of estimating the global solar radiation has been determined for twelve sites of Chad. The main results show that Abeche, a site in the Sahelian zone, has an radiation of $6.354 \mathrm{kWh} / \mathrm{m}^{2}$, while Ati has solar radiation of $5.523 \mathrm{kWh} / \mathrm{m}^{2}$. In the Saharan zone to the north, Faya-Largeau has the best solar radiation potential around $6.013 \mathrm{kWh} / \mathrm{m}^{2}$. In southern of Chad, the site with highest solar radiation is Bongor (with 5.839 $\mathrm{kWh} / \mathrm{m}^{2}$ ), but Sarh is the site with the lowest solar radiation of $5.751 \mathrm{kWh} / \mathrm{m}^{2}$. Three models, including the Angstrom-Prescott, Sabbagh and Allen models have been used to estimate the global solar radiation of each city, and these methods have been compared to the various statistical tests used to choose the appropriate model.

In terms of theoretical contributions, three equations were chosen:

$$
\begin{aligned}
& \text { Angstrom-Prescott Model : } H / H_{0}=0.3721+0.3659\left(S / S_{0}\right) \\
& \text { Allen Model : } H=0.6160 * H_{0} \\
& \text { Sabbagh Model : } H=3.7575 * 10^{3} * \exp L\left(\frac{S}{S_{0}}-\frac{R H^{1 / 3}}{100}-\frac{1}{T_{\max }}\right)
\end{aligned}
$$

\section{Acknowledgements}

The authors would like to thank the persons in charge of the National Meteorology for Chad, that of Bongor as well as the personnel who deal with the collection and the processing weather data on these sites, to have placed at our disposal the data used in this work.

\section{References}

[1] El-Sebaii, A.A., Al-Hazmi, F.S., Al-Ghamdi, A.A. and Yaghmour, S.J. (2010) Global, 
Direct and Diffuse Solar Radiation on Horizontal and Tilted Surfaces in Jeddah, Saudi Arabia. Applied Energy, 87, 568-576.

https://doi.org/10.1016/j.apenergy.2009.06.032

[2] Almorox, J., Hontoria C.and Benito, M. (2011) Models for Obtaining Daily Global solar Radiation with Measured Air Temperature Data in Madrid (Spain). Applied Energy, 88, 1703-1709. https://doi.org/10.1016/j.apenergy.2010.11.003

[3] Boukelia, T.E., Mecibah, M. and Meriche, I.E. (2014) General Models for Estimation of the Monthly Mean Daily Diffuse Solar Radiation (Case Study: Algeria). Energy Conversion and Management, 81, 211-219. https://doi.org/10.1016/j.enconman.2014.02.035

[4] Iziomon, M.G. and Mayer, H. (2002) Assessment of Some Global Solar Radiation Parameterizations. Journal of Atmospheric and Solar-Terrestrial Physics, 64, 1631-1643. https://doi.org/10.1016/S1364-6826(02)00131-1

[5] Chen, R., Ersi, K., Yang, J., Lu, S. and Zhao, W. (2004) Validation of Five Global Radiation Models with Measured Daily Data in China. Energy Conversion and Management, 45, 1759-1769. https://doi.org/10.1016/j.enconman.2003.09.019

[6] Li, H., Cao, F., Bu, X. and Zhao, L. (2015) Models for Calculating Daily Global Solar Radiation from Air Temperature in Humid Regions-A Case Study. Environmental Progress \& Sustainable Energy, 34, 595-599. https://doi.org/10.1002/ep.12018

[7] Bristow, K.L. and Campbell, G.S. (1984) On the Relationship between Incoming Solar Radiation and Daily Maximum and Minimum Temperature. Agricultural and Forest Meteorology, 31, 159-166. https://doi.org/10.1016/0168-1923(84)90017-0

[8] Donatelli, M. and Campbell, G.S. (1998) A Simple Model to Estimate Global Solar Radiation. In: Zima, M. and Bartosova, M.L., Eds., Proceedings of the Fifth European Society of Agronomy Congress, Nitra, 133-134.

[9] Goodin, D.G., Hutchinson, J., Vanderlip, R.L. and Knapp, M. (1999) Estimating Solar Irradiance for Crop Modeling Using Daily Air Temperature Data. Agronomy Journal, 91, 845-851. https://doi.org/10.2134/agronj1999.915845x

[10] Benghanem, M. and Mellit, A. (2014) A Simplified Calibrated Model for Estimating Daily Global Solar Radiationin Madinah, Saudi Arabia. Theoretical and Applied Climatology, 115, 197-205. https://doi.org/10.1007/s00704-013-0884-2

[11] Allen, R. (1995) Evaluation of Procedures for Estimating Mean Monthly Solar Radiation from Air Temperature. Food and Agriculture Organization of the United Nations.

[12] Annandale, J., Jovanovic, N., Benade, N. and Allen, R. (2002) Software for Missing Data Error Analysis of Penman-Monteith Reference Evapotranspiration. Irrigation Science, 21, 57-67. https://doi.org/10.1007/s002710100047

[13] Angstrom, A. (1924) Solar and Terrestrial Radiation. Report to the International Commission for Solar Research on Actinometric Investigations of Solar and Atmospheric Radiation. Quarterly Journal of the Royal Meteorological Society, 50, 121-126. https://doi.org/10.1002/qj.49705021008

[14] Prescott, J. (1940) Evaporation from a Water Surface in Relation to Solar Radiation. Transactions of the Royal Society of South Australia, 64, 114-118.

[15] Teke, A. and Yıldırım, H.B. (2014) Estimating the Monthly Global Solar Radiation for Eastern Mediterranean Region. Energy Conversion and Management, 87, 628-635. https://doi.org/10.1016/j.enconman.2014.07.052

[16] Al-Mostafa, Z.A., Maghrabi, A.H. and Al-Shehri, S.M. (2014) Sunshine-Based Global Radiation Models: A Review and Case Study. Energy Conversion and Man- 
agement, 84, 209-216. https://doi.org/10.1016/j.enconman.2014.04.021

[17] Toğrul, I.T. and Onat, E. (1999) A Study for Estimating Solar Radiation in Elazig Using Geographical and Meteorological Data. Energy Conversion and Management, 40, 1577-1584. https://doi.org/10.1016/S0196-8904(99)00035-7

[18] Skeiker, K. (2006) Correlation of Global Solar Radiation with Common Geographical and Meteorological Parameters for Damascus Province, Syria. Energy Conversion and Management, 47, 331-345. https://doi.org/10.1016/j.enconman.2005.04.012

[19] Tadros, M.T.Y. (2000) Uses of Sunshine Duration to Estimate the Global Solar Radiation over Eight Meteorological Stations in Egypt. Renewable Energy, 21, 231-246. https://doi.org/10.1016/S0960-1481(00)00009-4

[20] Soulouknga, H.M., Coulibaly, O., Doka, S.Y. and Kofane, T.C. (2017) Evaluation of Global Solar Radiation from Meteorological Data in the Sahelian Zone of Chad. Renewables. Wind, Water, and Solar, 4, 1-10. https://doi.org/10.1186/s40807-017-0041-0

[21] Sarkar, Md.N.I. (2016) Estimation of Solar Radiation from Cloud Cover Data of Bangladesh. Renewables. Wind, Water, and Solar, 3, 11.

https://doi.org/10.1186/s40807-016-0031-7

[22] Ayodele, T.R. and Ogunjuyigbe, A.S.O. (2015) Prediction of Monthly Average Global Solar Radiation Based on Statistical Distribution of Clearness Index. Energy, 90, 1733-1742. https://doi.org/10.1016/j.energy.2015.06.137

[23] Liu, Y.H. and Jordan, R.C. (1960) The Inter Relationship and Characteristic Distribution of Direct, Diffuse and Total Solar Radiation from Meterological Data. Solar Energy, 4, 1-19. https://doi.org/10.1016/0038-092X(60)90062-1

[24] Jain, A., Mehta, R. and Mittal, S.K. (2011) Modeling Impact of Solar Radiation Onsite selection for Solar PV Power Plants in India. International Journal of Green Energy, 8, 486-498. https://doi.org/10.1080/15435075.2011.576293

[25] Kumar, R. and Umanand, L. (2005) Estimation of Global Radiation Using Clearness index Model for Sizing Photovoltaic System. Renew Energy, 30, 2221-2233. https://doi.org/10.1016/j.renene.2005.02.009

[26] Khorasanizadeh, H. and Mohammadi, K. (2013) Prediction of Daily Global Solar Radiation by Day of the Year in Four Cities Located in the Sunny Regions of Iran. Energy Conversion and Management, 76, 385-392. https://doi.org/10.1016/j.enconman.2013.07.073

[27] Karakoti, I., Das, P.K. and Singh, S.K. (2012) Predicting Monthly Mean Daily Diffuse Radiation for India. Applied Energy, 91, 412-425. https://doi.org/10.1016/j.apenergy.2011.10.012

[28] Hassan, G.E., Youssef, M.E., Zahraa, E., Mohamed, A.A. and Hanafy, A.A. (2016) New Temperature-Based Models for Predicting Global Solar Radiation. Applied Energy, 179, 437-450. https://doi.org/10.1016/j.apenergy.2016.07.006

[29] Gana, N.N. and Akpootu, D.O. (2013) Angstrom Type Empirical Correlation for Estimating Global Solar Radiation in North-Eastern Nigeria. The International Journal of Engineering and Science, 2, 58-78.

[30] Musa, B., Zangina, U. and Aminu, M. (2012) Estimation of Global Solar Radiation in Maiduguri, Nigeria Using Angstrom Model. ARPN Journal of Engineering and Applied Sciences, 7, 1623-1627.

[31] Gairaa, K. and Bakelli, Y. (2013) A Comparative Study of Some Regression Models to Estimate the Global Solar Radiation on a Horizontal Surface from Sunshine Duration and Meteorological Parameters for Ghardaïa Site, Algeria. Hindawi Publish- 
ing Corporation. ISRN Renewable Energy, Article ID: 754956, 11 p.

[32] Ayangma, F., Nkeng, G.E., Bonoma, D.B. and Nganhou, J. (2008) Evaluation du potentiel en énergie solaire au cameroun: Cas du nordcameroun. African Journal of Science and Technology, 9, 32-40.

[33] Augustine, C. and Nnabuchi, M.N. (2010) Analysis of Some Meteorological Data for Some Selected Cities in the Eastern and Southern Zone of Nigeria. African Journal of Environmental Science and Technology, 4, 092-099.

[34] Khorasanizadeh, H. and Mohammadi, K. (2013) Introducing the Best Model for Predicting the Monthly Mean Global Solar Radiation over Six Major Cities of Iran. Energy, 51, 257-266. https://doi.org/10.1016/j.energy.2012.11.007

[35] Allen, R.G.A. (1997) Self Calibraing Method for Estimating Solar Radiation from Air Temperature. Journal of Hydrologic Engineering, 2, 56-57. https://doi.org/10.1061/(ASCE)1084-0699(1997)2:2(56)

[36] Katiyar, A.K. and Pandey, C.K. (2013) A Review of Solar Radiation Models-Part 1. Journal of Renewable Energy, 2013, Article ID: 168048. https://doi.org/10.1155/2013/168048

[37] Sabbagh, J.A., Sayigh, A.A.M. and El-Salam, E.M.A. (1977) Estimation of the Total Solar Radiation from Meteorological Data. Solar Energy, 19, 307-311. https://doi.org/10.1016/0038-092X(77)90075-5

[38] Argungu, G.M., Bala, E.J., Momoh, M., Musa M., Dabai, K.A. and Zangina, U. (2013) Statistical Analysis of Wind Energy Resource Potentials for Power Generation in Jos, Nigeria, Based on Weibull Distribution Function. The International Journal of Engineering and Science, 2, 22-31.

[39] Despotovic, M., Nedic, V., Despotovic, D. and Vetanovic, C.S. (2015) Review and Statistical Analysis of Different Global Solar Radiation Sunshine Models. Renewable and Sustainable Energy Reviews, 52, 1869-1880.

https://doi.org/10.1016/j.rser.2015.08.035

[40] Li, H., Ma, W., Lian, Y. and Wang, X. (2010) Estimating Daily Global Solar Radiation by Day of Year in China. Applied Energy, 87, 3011-3017. https://doi.org/10.1016/j.apenergy.2010.03.028

[41] Ajayi, O.O., Ohijeagbon, O.D., Nwadialo, C.E. and Olasope, O. (2014) New Model to Estimate Daily Global Solar Radiation over Nigeria. Sustainable Energy Technologies and Assessments, 5, 28-36. https://doi.org/10.1016/j.seta.2013.11.001

[42] Sözen, A. and Arcaklioglu, E. (2005) Solar Potential in Turkey. Applied Energy, 80, 35-45. https://doi.org/10.1016/j.apenergy.2004.02.003 